\title{
Egg parasitoids of the genus Trichogramma (Hymenoptera, Trichogrammatidae) in olive groves of the Mediterranean region
}

\author{
Annette Herz ${ }^{a, *}$, Sherif A. Hassan ${ }^{a}$, Esmat Hegazi ${ }^{b}$, Wedad E. Khafagi ${ }^{c}$, Feeby N. Nasr ${ }^{c}$, \\ Ali I. Youssef ${ }^{c}$, Essam Agamy ${ }^{d}$, Imen Blibech ${ }^{\mathrm{e}}$, Ines Ksentini ${ }^{\mathrm{e}}$, Mohieddine Ksantini ${ }^{\mathrm{e}}$, \\ Taieb Jardak ${ }^{\mathrm{e}}$, Albino Bento ${ }^{\mathrm{f}}$, José A. Pereira ${ }^{\mathrm{f}}$, Laura Torres ${ }^{\mathrm{g}}$, Costas Souliotis ${ }^{\mathrm{h}}$, \\ Theodorus Moschos ${ }^{\mathrm{h}}$, Panos Milonas ${ }^{\mathrm{h}}$ \\ ${ }^{a}$ Federal Biological Research Centre for Agriculture and Forestry, Institute for Biological Control, Darmstadt, Germany \\ ${ }^{\mathrm{b}}$ University of Alexandria, Faculty of Agriculture, Egypt \\ ${ }^{c}$ Plant Protection Research Institute, Agriculture Research Station, El-Sabahia, Alexandria, Egypt \\ d Cairo University, Faculty of Agriculture, Biological Control Laboratory, Giza, Egypt \\ e Institute de L'Olivier, Sfax, Tunisia \\ ${ }^{\mathrm{f}}$ Instituto Politécnico de Bragança, Bragança, Portugal \\ ${ }^{g}$ Universidade de Trás-os-Montes e Alto Douro, Vila Real, Portugal \\ h Benaki Phytopathological Institute, Athens, Greece
}

Received 9 March 2006; accepted 8 August 2006

Available online 15 August 2006

\begin{abstract}
A survey of egg parasitoids of the genus Trichogramma (Hymenoptera, Trichogrammatidae) was carried out in olive groves in Portugal, Greece, Egypt, and Tunisia during the years 2002-2004. Parasitoids were obtained either by exposing sentinel eggs (Sitotroga cerealella Olivier or Ephestia kuehniella Zeller) on olive trees or by collecting eggs of lepidopterous olive pests. Parasitized egg samples were reared separately in the laboratory for emergence of parasitoids. These were further reared in separate lines and processed by morphological and molecular biology techniques for species characterization. The recorded fauna of Trichogramma parasitoids in olive groves was species poor and consisted of species mainly known from the Mediterranean region. Trichogramma bourarachae Pintureau and Babault was found in Tunisia and Egypt, T. cordubensis Vargas and Cabello, and T. euproctidis Girault in Egypt, Trichogramma cacoeciae Marchal in Portugal, Greece, Egypt, Tunisia and Trichogramma nerudai Pintureau and Gerding in Portugal. Apart from that, Trichogramma oleae Voegelé and Pointel was collected in Tunisia. This species is probably not indigenous, but has established after several releases of a French strain were made in recent years. For selected strains, the sequence of the internal transcribed spacer 2 (ITS-2) region of rDNA was determined and deposited in the GenBank database. Differences in important biological attributes were found among collected strains of $T$. bourarachae, suggesting the existence of biotypes. The results contribute to the limited knowledge on distribution and biodiversity of the genus Trichogramma in the Mediterranean region. They can be helpful for the preservation and use of indigenous Trichogramma species in biological control of lepidopterous pests in olive and other local crops.
\end{abstract}

(C) 2006 Elsevier Inc. All rights reserved.

Keywords: Trichogramma bourarachae; Trichogramma cordubensis; Trichogramma euproctidis; Trichogramma cacoeciae; Trichogramma nerudai; Trichogramma oleae; ITS-2 region; Olive cultivation; Biodiversity; Biocontrol agent; Prays oleae; Palpita unionalis; Mediterranean region

\footnotetext{
* Corresponding author. Fax: +4962218680515.

E-mail address: A.Herz@bba.de (A. Herz).
}

\section{Introduction}

The cultivation of the olive tree, Olea europea L., is of socio-economic and ecological importance for the Mediterranean region since ancient times. Current olive growing 
spans from traditional techniques to intensively managed plantations and create a large diversity of ecological conditions. In several Mediterranean countries, e.g., Tunisia, Spain, or Greece, the olive tree is the landscape determining factor. Hence, the olive grove ecosystem is an important reservoir for biodiversity in this region (Rey, 1995; Cirio, 1997; Beaufoy, 2000, 2001).

Egg parasitoids of the genus Trichogramma are keystone natural enemies of many lepidopterous pests in agriculture and forestry $(\mathrm{Li}, 1994)$. More than 150 different species are known from various biotopes (Pinto and Stouthamer, 1994; Pinto, 1999). These minute parasitoids were considered excellent indicator species to study the side effects of pesticides on beneficial arthropods and the environment (Hassan, 1998). They are broadly distributed world wide, sensitive to pesticides compared to other hymenopterous parasitoids and they are effective natural enemies of various insect pests. Youssef et al. (2004) has recently published the results of testing the side effects of pesticides that are used against olive pests on Trichogramma cacoeciae Marchal. Due to the toxicity of a number of the agrochemicals tested, a negative impact on Trichogramma that naturally occur in olive groves can be expected if broad spectrum insecticides are repeatedly used. The particular Trichogramma fauna of the olive agroecosystem is not well known. Only few reports exist in literature (Pelekassis, 1962; Jardak, 1980) but they suggest an important role of these egg parasitoids for natural control of olive pests (Arambourg, 1986).

Several insect species within the order Lepidoptera damage flowers, fruits or leaves of the olive tree (Arambourg, 1986). The field release of mass-reared Trichogramma is considered as a promising approach to control the olive moth, Prays oleae Bernard (Lepidoptera, Yponomeutidae) and the jasmine moth, Palpita unionalis Hübner (Lepidoptera, Pyralidae) in order to reduce pesticide application in olive growing (Hegazi et al., 2004, 2005; Herz et al., 2005; Herz and Hassan, 2006). At present, the European Plant Protection Organization (EPPO) lists the species Trichogramma brassicae Bezdenko, T. cacoeciae Marchal,
Trichogramma dendrolimi Matsamura, and Trichogramma evanescens Westwood for use in countries of the EuroMediterranean region (EPPO, 2002). But inundative releases of non-indigenous Trichogramma may have also adverse effects on non-target hosts and/or released parasitoids may compete with locally occurring Trichogramma (Louda et al., 2003). Preference should always be given to indigenous strains or species that are collected from the same region, when developing a new biocontrol program based on Trichogramma (Van Lenteren et al., 2003).

In the present study, a survey was carried out to record the local Trichogramma-fauna in olive groves in several countries of the Mediterranean region. One objective was to obtain essential data which allow to evaluate the risk for a potential shift in the egg parasitoid fauna after the application of plant protection measures. But most important was the aim to collect and characterize strains of Trichogramma for their potential use in biological control of olive pests (Herz et al., 2005). Native strains are more likely to be adapted to the olive tree environment, the target pests and the weather conditions of the region.

\section{Materials and methods}

\subsection{Description of the study areas}

Several olive groves located in various areas in Portugal, Tunisia, Greece, and Egypt were sampled during spring and summer of the years 2002, 2003, and 2004. The groves varied in age, environmental conditions and cultivation techniques, but represented typical olive growing conditions of the particular region (Table 1).

\subsection{Field collection of Trichogramma}

Recording of the Trichogramma-fauna was mainly done by exposure of sentinel eggs which were put in particular baiting devices. These consisted of small plastic frames $(2 \times 2 \mathrm{~cm})$, covered from both sides with fine nylon or metal mesh to allow access of small Trichogramma-wasps, but

Table 1

Location and type of the olive groves included in the survey for Trichogramma species in four countries in the Mediterranean region during the years 2002-2004

\begin{tabular}{lllll}
\hline & No. of olive groves surveyed & Region & Locations & Cultivation \\
\hline Egypt & $2(2002)$ & Alexandria (coast) & Bourg-el-Arab & Traditional olive grove \\
& $2(2003)$ & Cairo (desert) & Paradise Park & Young plantation \\
Greece & $2(2004)$ & Attikis region & Tanagra, Arma Viotias & IPM-cultivated olive groves \\
& $3(2002)$ & & & Organic olive groves \\
Portugal & $3(2003)$ & Alto Douro region & Mirandela, Macedo de Cavaleiros, & IPM-cultivated olive groves \\
& $3(2004)$ & & Vila Flor, Figueira de Castelo Rodrigo & Siris, Taous, Bir Mellouli, \\
Tunisia & $1(2002)$ & Sfax region & Ketetna, Zarzis & \\
& $1(2002)$ & & &
\end{tabular}


to prevent predation on the content inside. A small piece of paper with sentinel eggs (Sitotroga cerealella Olivier or Ephestia kuehniella Zeller depending on local availability) glued on was inserted in each device (Sakr et al., 2000). The device was fixed with a piece of wire close to branches or leaves of the olive tree (Hegazi et al., 2005). From 60 to 100 baiting devices were distributed on 6 to 10 randomly selected trees in each sampled olive grove. Also parasitized eggs of the olive moth and jasmine moth were collected in some cases. The survey started in early spring until late summer and sentinel eggs were replaced weekly. Collected samples were incubated separately in the laboratory in order to check for parasitism. Emerged parasitoids were reared in separate glass tubes and, after propagation, samples of parasitized eggs were sent for species characterization to the Institute for Biological Control in Darmstadt, Germany. Strains were propagated for at least one generation on Sitotroga eggs to obtain sufficient material for morphological and molecular biology studies. Vouchers of the original shipped samples were preserved in ethanol $(70 \%)$ as reference and added to the collection of the Institute for Biological Control, Darmstadt, Germany.

\subsection{Techniques for species characterization of collected strains}

Morphological differentiation between Trichogrammaspecies is mainly based on structures of the male genitalia and antennae (Pinto, 1999). Whole body mounts of males from field collected arrhenotokous strains were prepared in Hoyer's medium for examination of morphological characters, using a Zeiss Axioplan Stereomicroscope at a magnification range of $200 \times$ to $640 \times$. Examination of slides was done following descriptions of Sorokina (1993) and Pinto (1999). Specimens of selected strains were sent to Dr. Bernard Pintureau (Inst. Nat. Science Appl. de Lyon, Villeurbanne, France) for validation of results.

For molecular differentiation, size and sequence of the internal transcribed spacer 2 (ITS-2) region of rDNA of selected Trichogramma strains was examined following the procedures developed by Stouthamer et al. (1999) and Silva et al. (1999). For DNA-extraction, 5 specimens of each strain were ground in distilled water and incubated overnight at $56^{\circ} \mathrm{C}$ after adding Proteinase K. PCR-amplification was done by using the QIAGEN Taq PCR Core Kit and the primers $5^{\prime}>$ TGTGAACTGCAGGACA CATG $<3^{\prime}$ (forward) and $5^{\prime}>$ GTCTTGCCTGCTCT GAG $<3^{\prime}$ (reverse) (Silva et al., 1999). PCR-Products were separated by electrophoresis in $2 \%$ agarose-gels, stained with ethidium bromide and photographed under UV-light for visualizing DNA-bands. The ITS-2 PCR products were analyzed by restriction enzyme digestion (Silva et al., 1999) and comparison of obtained restriction patterns of field collected strains with well defined reference strains of the strain collection at the Institute for Biological Control. For sequencing of the ITS-2-region, DNA of individual wasps of selected strains was first amplified by PCR. Cleanup of the PCR-products was performed with the QIAGEN MinElute ${ }^{\mathrm{TM}}$ PCR purification Kit according to the protocol of the supplier and the samples were dispatched for bidirectionally sequencing with the primers above. Comparison of the obtained sequences with those published in GenBank was done by BLAST analysis (BLAST 2.2.14, Altschul et al., 1997). Complete ITS-2 sequences of determined strains were deposited in the Genbank database and sent to Dr. Richard Stouthammer (Department of Entomology, University of California, Riverside, USA) for validation of results.

In selected cases, crossing experiments and partial life table studies were conducted in order to test sexual compatibility between strains and to study variation in important biological attributes (fecundity, longevity, sex ratio, and developmental time) of strains. The testing procedures followed standard protocols developed at the Institute for Biological Control in Darmstadt (Hassan and Zhang, 2001).

\section{Results}

\subsection{Phenology and distribution of the Trichogramma-fauna in olive groves}

Parasitized samples (i.e., parasitized eggs in baiting devices or eggs of the olive moth or jasmine moth) were found during the whole collection period in spring and early summer (Fig. 1) when activity of arthropods was high in the olive groves. In 2003, the baiting was started earlier in spring and continued to late summer. In Egypt, sentinel eggs were also parasitized during January/February (rainy season, mean temperature: $8^{\circ} \mathrm{C}(\mathrm{min})$ to $19^{\circ} \mathrm{C}$ (max)) and in July/August (dry season, mean temperature: $20^{\circ} \mathrm{C}(\min )$ to $\left.35^{\circ} \mathrm{C}(\max )\right)$, indicating the activity of wasps during less favorable weather conditions. In Greece, parasitism was only detected in two samples in May and June 2004, although sampling was intense in several groves during the three years of the study (Table 1). In total, 170 samples that had positive parasitism were examined in the laboratory and resulted in the characterization of six Trichogramma species: T. bourarachae Pintureau and Babault, T. cacoeciae Marchal, T. cordubensis Vargas and Cabello, T. euproctidis Girault, T. nerudai Pintureau and Gerding, and T. oleae Voegelé and Pointel (Fig. 2). The characterization of the strains was considered as successful in the case of consistency of morphological and molecular data (except the record of $T$. nerudai, see below). T. cacoeciae was dominant in Portugal and Greece and $T$. oleae in Tunisia. Other species (T. nerudai in Portugal, $T$. bourarachae in Tunisia) occurred only sporadically. In Egypt, $T$. bourarachae was dominant at the grove in Bourg-el-Arab near Alexandria, whereas three other species ( $T$. cacoeciae, $T$. cordubensis, and T. euproctidis) were collected at the grove in Paradise Park near Cairo. 

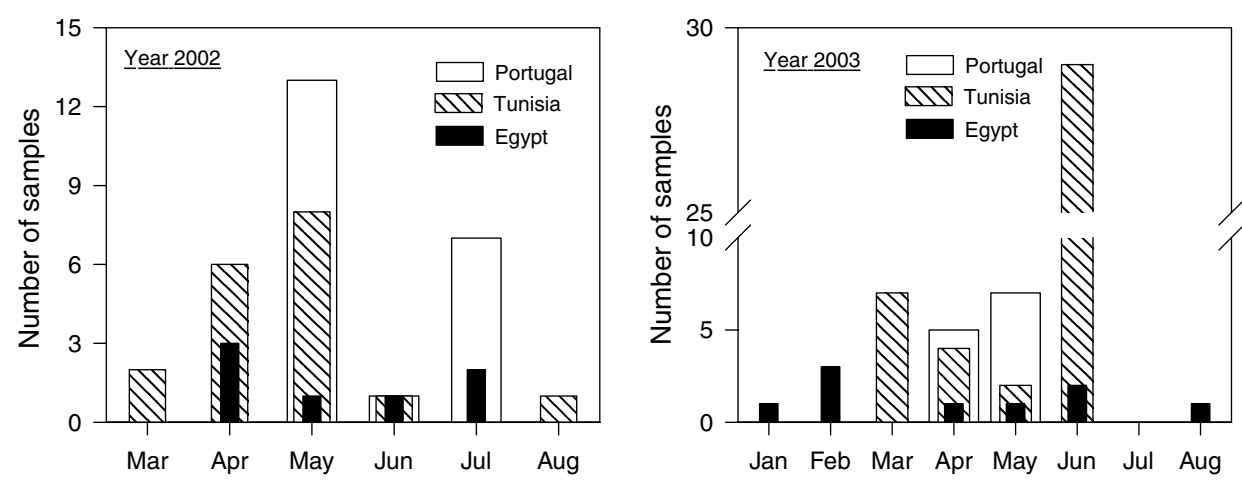

Fig. 1. Occurrence of Trichogramma egg parasitoids in olive groves in Portugal, Tunisia and Egypt in the years 2002 and 2003 . Weekly sampling was done by exposing sentinel eggs ( $S$. cerealella or E. kuehniella) or by collecting naturally occurring lepidopterous hosts $(P$. oleae and $P$. unionalis) in spring and summer.

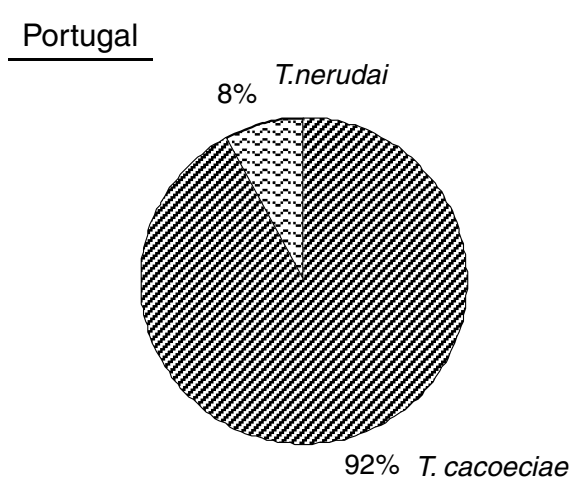

$\underline{\text { Egypt }}$
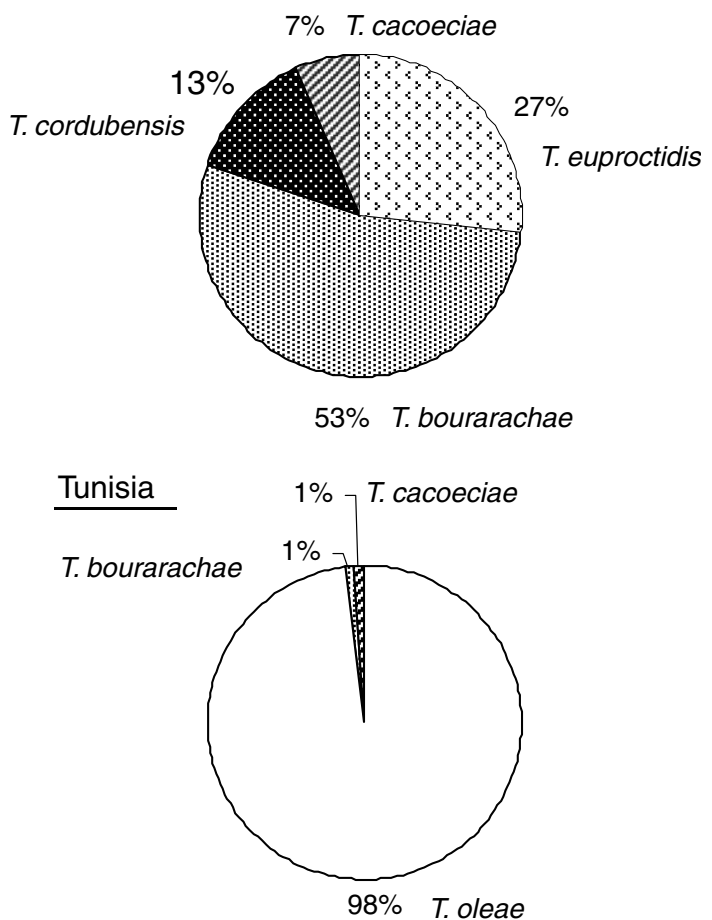

Fig. 2. Species diversity of Trichogramma egg parasitoids, collected in olive groves in Portugal, Tunisia and Egypt (samples obtained from 2002 to 2004). Weekly sampling was done by exposing sentinel eggs $(S$. cerealella or E. kuehniella) or by collecting naturally occurring lepidopterous hosts ( $P$. oleae and $P$. unionalis) in spring and summer.

\subsection{Description of Trichogramma species collected in olive groves}

\subsubsection{Trichogramma bourarachae Pintureau and Babault}

Strains of this species were collected in Egypt as well as in Tunisia. In Egypt, this species was collected from one location (Bourg-el-Arab), but regularly in 2002 (5 samples) as well as in 2003 (4 samples) and 2004 (8 samples). In Tunisia, one sample was collected end of May 2002 at Siris and one sample in June 2003 at Zarzis, both located in the olive growing region around Sfax. A further sample was obtained from eggs of the carob moth (Ectomyelois ceratoniae Zeller) on pomegranate in a house garden at Sfax. The species has an arrhenotokous reproduction and both males and females are dark gray colored. ITS2-sequences of Egyptian and Tunisian strains were similar in size (555 to $559 \mathrm{bp}$, Table 2). Crossings between these strains $($ TP41EG $\times$ TP49TN) demonstrated sexual compatibility with $64 \%$ female progeny in the F1-generation and $41 \%$ female progeny in the F2-generation. But the strains differed in several biological attributes (Table 3). The Tunisian strain of $T$. bourarachae ("TP49TN") developed within 17 days and thus 1 to 3 days faster than other collected strains of this species (strains "TP1EG", "TP41EG" and "TP58EG" from Egypt). It had the highest fecundity with 17.9 eggs per female and day, but was short-lived. Samples obtained from Egypt (strains "TP1EG", "TP41EG", and "TP58EG") were more similar to each other, especially regarding developmental time (around 18 days) and fecundity (10 to 13 eggs per female and day). Compared to these results, a Portuguese strain of T. bourarachae ("Tb26") which had been collected from noctuid host eggs in tomato in 1992 (Silva et al. (1999)), needed longer for development (20 days), laid fewer eggs (6.7 eggs per female and day), but lived much longer. All strains of $T$. bourarachae produced about $40 \%$ males in the progeny at $25^{\circ} \mathrm{C}$.

\subsubsection{Trichogramma cacoeciae Marchal}

This species was collected in all four countries (Portugal: 22 samples, Tunisia: 2 samples, Egypt: 2 samples, and 
Table 2

Analysis of the ITS-2-region of selected Trichogramma-strains collected in olive groves in four countries in the Mediterranean region 2002-2004

\begin{tabular}{|c|c|c|c|c|c|}
\hline Species $^{\mathrm{a}}$ & Strain ID $^{\mathrm{b}}$ & Collection in & Size of ITS-2 [bp] & GenBank ID ${ }^{c}$ & BLAST (version 2.2.14) alignment with sequence of species ${ }^{\mathrm{d}}$ \\
\hline T. bourarachae & TP1EG & Egypt, 2002 & 557 & DQ389071 & AF043624 (T. bourarachae, sample Tb262) \\
\hline T. bourarachae & TP41EG & Egypt, 2002 & 558 & DQ389072 & AF043624 (T. bourarachae, sample Tb262) \\
\hline T. bourarachae & TP49TN & Tunisia, 2002 & 555 & DQ389073 & AF043624 ( $T$. bourarachae, sample Tb262) \\
\hline T. cacoeciae & TP97GR & Greece, 2004 & 466 & DQ389075 & AF408653 (T. cacoeciae, strain CACB) \\
\hline T. cordubensis & TP52EG & Egypt, 2003 & Partial & - & AF043619 (T. cordubensis, strain Tc14) \\
\hline T. cordubensis & TP63EG & Egypt, 2004 & 408 & DQ389074 & AF043619 (T. cordubensis, strain Tc14) \\
\hline T. euproctidis & TP42EG & Egypt, 2002 & 376 & DQ389076 & AF043614 (T. turkestanica, strain Tt2) \\
\hline T. nerudai & TP23PT & Portugal, 2003 & 635 & DQ872853 & AY244467 (T. nerudai), strain "Chile" \\
\hline T. oleae & IO47 & Tunisia, 2003 & 403 & DQ389070 & U74601 (T. oleae) \\
\hline
\end{tabular}

a Species identification according to molecular and morphological data.

b Strain code in the strain collection at the Institute for Biological Control.

c Accession number of sequence in GenBank.

$\mathrm{d}$ Accession number of ITS2-sequences, published in GenBank, giving the highest identity score in a BLAST-alignment $(E$-value $=0)$.

Table 3

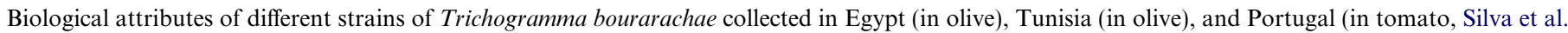
(1999)) in the laboratory at $25^{\circ} \mathrm{C}, 70 \% \mathrm{RH}, \mathrm{L} / \mathrm{D}=16 / 8 \mathrm{~h}$

\begin{tabular}{|c|c|c|c|c|c|}
\hline Strain ID $^{\mathrm{a}}$ & Origin & Developmental time [days] & Daily number of eggs/female & Survival D7 $[\%]^{\mathrm{b}}$ & Sex ratio $[\%$ males $]$ \\
\hline TP1EG & Egypt, 2002 & $18.1 \pm 1.5$ & $10.0 \pm 3.0$ & 60 & No data \\
\hline TP41EG & Egypt, 2003 & $18.4 \pm 1.0$ & $10.7 \pm 5.2$ & 49 & $41 \pm 26$ \\
\hline TP58EG & Egypt, 2004 & $18.8 \pm 1.3$ & $12.9 \pm 9.6$ & 69 & $40 \pm 25$ \\
\hline TP49TN & Tunisia, 2002 & $17.1 \pm 1.5$ & $17.9 \pm 8.8$ & 27 & $42 \pm 27$ \\
\hline $\mathrm{Tb} 26$ & Portugal, 1992 & $20.3 \pm 1.8$ & $6.7 \pm 4.7$ & 85 & $36 \pm 27$ \\
\hline
\end{tabular}

Values are means $\pm \mathrm{SD}$.

a Strain code in the strain collection at the Institute for Biological Control.

b Survival in percentage of the initial number of females ( $n=15$ females, 3 replicates) until day seven of the experiment.

Greece: 2 samples). T. cacoeciae is a thelytokous species with a broad geographic distribution (Pinto, 1999). From literature, it is known that this species is mainly found in arboreal habitats like forests and orchards and the natural occurrence in olive groves is expected. The size of the ITS-2 PCR product of these strains was assessed as $580 \mathrm{bp}$ in agarose gel electrophoresis. The sequence of the ITS-2 region of a Greek strain consisted of 466 bp (Table 2).

\subsubsection{Trichogramma cordubensis Vargas and Cabello}

Several samples of this species were collected in the young olive plantation at Paradise Park, Cairo, from eggs of the jasmine moth in January/February 2003 and in February 2004, respectively. T. cordubensis is a thelytokous species. Rearing of strains ("TP52EG", "TP63EG") at higher temperature (alternating regime of $25 / 35^{\circ} \mathrm{C}$ ) resulted in $5 \%$ of males and gynandropomorphs in the progeny. Examination of the male genital capsule, PCR studies as well as digests of the ITS-2 PCR product [size $520 \mathrm{bp}$ ] by the restriction enzymes EcoRI and $M n / I$ were performed in comparison to a reference strain (strain "Tc14", described in Silva et al. (1999)). These data as well as subsequent sequencing of the ITS-2 region and BLAST-analysis suggested the identity of these strains as $T$. cordubensis (Table 2).

\subsubsection{Trichogramma euproctidis Girault}

This arrhenotokous species was collected several times in the young olive plantation at Paradise Park, Cairo, during 2002 and 2003. It was first identified as Trichogramma pretiosum (Hegazi et al., 2005), but further work on morphological and molecular characters (color, kind of reproduction, size of the ITS-2 PCR product (490 bp, Silva et al., 1999)) suggested relationship to the species Trichogramma turkestanica Meyer, synonym of Trichogramma meyeri Sorokina. Whole body mounts of single specimen (strain "TP42EG") were identified as T. euproctidis Girauld (B. Pintureau, pers. communication) which is considered as synonym of $T$. turkestanica and $T$. meyeri according to Rohi and Pintureau (2003a). The BLASTalignment of the ITS2-sequence suggested consistency with that of a Portuguese strain of $T$. turkestanica, studied by Silva et al. (1999).

\subsubsection{Trichogramma nerudai Pintureau and Gerding}

This species was collected in May 2002 and June 2003 at Figueira de Castelo Rodrigo, North-Eastern Portugal. It produced both males and females of dark gray coloring. Sex ratio was strongly female-biased ( $>80 \%$ females). The morphology of the male genital capsule allowed the assignment to the parkeri section described by Pinto (1999) and here to T. bourarachae (B. Pintureau, pers. communication). However, collected wasps (strains "TP23PT", "TP57PT") could be clearly separated by the size of the ITS-2 PCR product $(730 \mathrm{bp})$ from the other strains obtained in the olive grove ecosystem. BLAST-analysis of the ITS-2 sequence $(635 \mathrm{bp})$ resulted in the identification 
Table 4

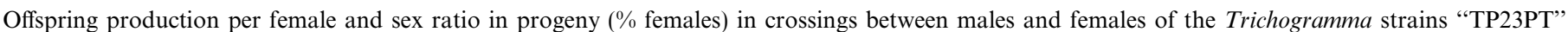

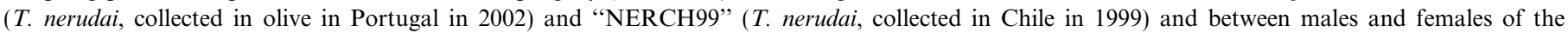
F1-Generation. 10 replicates of each crossing were performed and eggs of $S$. cereallela were offered for seven days at $25{ }^{\circ} \mathrm{C}, 70 \% \mathrm{RH}$, (L/D: $\left.16: 8 \mathrm{~h}\right)$

\begin{tabular}{|c|c|c|c|c|c|}
\hline & \multicolumn{2}{|c|}{ TP23PT female $\mathrm{x}$} & & \multicolumn{2}{|c|}{ NERCH99 female $x$} \\
\hline & $\sum$ Offspring & $\%$ Females & & $\sum$ Offspring & $\%$ Females \\
\hline Without male & $21 \pm 25$ & 0 & Without male & $55 \pm 16$ & 0 \\
\hline TP23PT male & $33 \pm 14$ & 84.8 & NERCH99 male & $60 \pm 30$ & 56.3 \\
\hline \multirow[t]{3}{*}{ NERCH99 male } & $41 \pm 27$ & 50.4 & TP23PT male & $41 \pm 12$ & 69.1 \\
\hline & \multicolumn{3}{|c|}{ F1 males $\times$ F1 females } & \multicolumn{2}{|c|}{$\mathrm{F} 1$ males $\times \mathrm{F} 1$ females } \\
\hline & $145 \pm 51$ & 69.8 & & $41 \pm 11$ & 87 \\
\hline
\end{tabular}

as T. nerudai Pintureau and Gerding (Table 2), which is known only from Chile so far (Pintureau et al., 1999). A crossing experiment between the Portuguese strain "TP23PT" and a strain of T. nerudai (strain "NERCH99"), collected in Chile, resulted in fertile F1-females (50 and $70 \%$ of the progeny), indicating sexual compatibility between strains (Table 4). In contrast, crossings between "TP23PT" and a Portuguese strain of T. bourarachae ("Tb26") did not produce females in the F1-generation.

\subsubsection{Trichogramma oleae Voegelé and Pointel}

This species is not known to be indigenous to Tunisia, but was repeatedly released by the Institute de l'Olivier since 1986 in several olive groves in the Sfax region. During this study, parasitized sentinel eggs were obtained from sites where no releases had been made before. The size of the ITS-2 PCR product of examined wasps was estimated as $500 \mathrm{bp}$ in agarose gel electrophoresis. The ITS-2 sequence of individuals from the field-collected strain "IO47" (403 bp)] was identical with that obtained from the original strain " $2 \mathrm{~F}$ ", imported from France and reared at the Institute de l'Olivier in Tunisia, and revealed 98\% identity with the already published sequence of $T$. oleae in GenBank (Schilthuizen and Stouthamer, 1997; Table 2). $T$. oleae was the most frequent species recorded in Tunisia in this survey, but it was not found in the other countries. $T$. oleae is known as thelytokous species.

\section{Discussion}

According to our results in the four countries surveyed, natural communities of Trichogramma parasitoids in olive groves are composed of only few species. Mainly species previously recorded from the Mediterranean region were found: $T$. bourarachae, $T$. cordubensis, $T$. euproctidis (=turkestanica), and $T$. oleae. Furthermore, the typical arboreal species $T$. cacoeciae as well as $T$. nerudai were collected. Low diversity of the Trichogramma fauna was observed in similar studies conducted in particular biotopes or agroecosystems. Three species (Trichogramma fuentesi Torre, Trichogramma retorridum Girault, and $T$. pretiosum Riley) were collected in a survey of naturally occurring egg parasitoids in sugarcane in Texas (Browning and Melton,
1987). In vineyards of Alsace, Barnay et al. (2001) found four native species ( $T$. cacoeciae, $T$. daumalae Dugast and Voegelé, and T. evanescens Westwood, T. principium Sugonjaev and Sorokina). Glenn and Hoffmann (1997) recorded five species in vineyards in South Australia (Trichogramma carverae Oatmann and Pinto, Trichogramma funiculatum Carver, T. sp. $x$, Trichogramma nr. brassicae, Trichogrammatoidea sp. nr. bactrae). The occurrence of up to five species ( T. bourarachae, T. cordubensis, T. evanescens, Trichogramma pintoi Voegelé, and T. turkestanica) in tomato fields of Portugal was confirmed by a recent study of Gonçalves et al. (2006). Two species (T. cacoeciae, $T$. evanescens) were found in vineyards in Rheingau/Germany by Ibrahim et al. (2004). Arboreal habitats are often dominated by one species, for instance $T$. cacoeciae in European forests (Walter, 1982) and apple orchards (Sakr, 2003) and Trichogramma minutum Riley in peach orchards (Atanassov et al., 2003) and spruce forests (Quayle et al., 2003) in North America. According to our results, also the olive grove ecosystem was dominated by one particular species of Trichogramma ( $T$. cacoeciae in Portugal and Greece, T. oleae in Tunisia, and T. bourarachae in Egypt).

Natural egg parasitism of lepidopterous key olive pests like the olive moth or the jasmine moth was low in the olive groves surveyed $(<17 \%$ in Egypt (Hegazi et al., 2005) and $<1 \%$ in the other countries) and only $10 \%$ of the examined samples were obtained from naturally occurring host eggs. Pest control by naturally occurring Trichogramma egg parasitoids was insufficient and augmentative releases of reared wasps are needed. The strains described in this study could all be easily propagated on factitious hosts $(S$. cereallela, E. kuehniella), thus indicating their potential for mass production, one important prerequisite for their use as biological control agents.

In the present study, more Trichogramma-species were found in Egypt (4 species) compared to the other countries of the study, although only two locations were sampled. These two locations represented two distinct types of olive groves, situated in different regions (Table 1): the location "Bourg-el-Arab" represented a traditional grove with high vegetation diversity, where also apple, peach, guava, fig, and almond trees were grown. Insecticides were seldom applied in this grove. It was located at the coast and rainfed under semi-arid weather conditions. T. bourarachae 
was frequently collected in this biotope. In contrast, the grove "Paradise-Park" represented a young intensively managed plantation under arid weather conditions. T. bourarachae was not found there. Perhaps this species did not manage to spread into this recently established olive growing region because of the surrounding desert. Date palms as well as ornamental shrubs were also grown in Paradise Park, thus sustaining other potential lepidopterous host species as well as their specific natural enemies. The jasmine moth was common in higher densities and throughout the season on olive trees in Paradise Park, probably because young irrigated olive plantations are the preferred habitat of this pest. T. cordubensis was isolated several times from eggs of this host, indicating preference. In other studies, we found this species promising for use in the biological control of $P$. unionalis, supporting the idea of selecting indigenous biological control agents adapted to the pest/crop system (Herz and Hassan, 2006).

According to literature references, both $T$. bourarachae and $T$. cordubensis are known to be generally abundant and typical for the Mediterranean area (Table 5). T. cordubensis was described by Vargas and Cabello (1985) which obtained this species from eggs of Helicoverpa armigera Hübner in Spain. It was also found in Morocco and Algeria on eggs of the carob moth (E. ceratoniae) as well as of $H$. armigera (Pintureau and Babault, 1988) and was obtained in Portugal from noctuid eggs (Silva et al., 1999; Gonçalves et al., 2006). The first description of $T$. bourarachae was based on specimens who originated in Morocco and had been collected from eggs of H. armigera (Pintureau and Babault, 1988). It is also known from Portugal from noctuid eggs (Silva et al., 1999; Gonçalves et al., 2006). The results of our survey contributed to the knowledge of the geographic distribution of these both species as this was the first record of $T$. bourarachae in Tunisia and Egypt and of T. cordubensis in Egypt. According to literature and our observations, they were isolated from important target pests in the Mediterranean region (E. ceratoniae, H. armigera, and P. unionalis), indicating their potential for use in biocontrol programs. But for $T$. bourarachae, we also found differences in important biological attributes (fecundity, survival, developmental time) between strains from Egypt, Tunisia, and Portugal, showing the importance of selecting the appropriate biotype suitable for biological control (Unruh and Messing, 1993).

Trichogramma nerudai was recently discovered in Chile on eggs of the European pine shoot moth, Rhyacionia buoliana Denis and Schiffermüller (Pintureau et al., 1999). The species is currently under investigation for use in biological control of $R$. buoliana and other pests in South America (Gerding et al., 1996; Tezze and Botto, 2004). The reported record of this species in Portugal is the first one outside Chile. Further molecular studies are needed to prove the degree of relationship between the Portuguese and Chilean strain, also concerning a potential immigration of this species from South America to Europe or vice versa.

Based on our results, it is not possible to determine if $T$. oleae is native to Tunisia or not. Our data suggested successful dispersion and establishment of this species after several releases of a French strain were made in the past in Tunisia. However, natural egg parasitism of important olive pests was low and other hosts may sustain the existence of this species in the olive grove ecosystem. Our study points on the need for monitoring the existing Trichogram$m a$ fauna in a particular area before inundative releases of species are conducted for the first time. Only then it is possible to detect any shifts in the local egg parasitoid community after release of a potentially exotic species.

We are aware of the fact that the results of this survey may give an incomplete picture of the real existing Trichogramma fauna in the Mediterranean olive region. Most samples were obtained from sentinel eggs of the factitious hosts $S$. cerealella and E. kuehniella. There is the risk of sampling bias by excluding those species which did not accept these eggs. However, eggs of target pests like the olive moth and jasmine moth are quite small and are laid singly or in small clusters and thus they are not easy to collect. A high predation on egg cards within the baiting

Table 5

Host associations of $T$. cordubensis and T. bourarachae according to literature and collection data obtained in this study

\begin{tabular}{llll}
\hline Host & Crop & Collection & Reference \\
\hline $\begin{array}{l}\text { T. cordubensis } \text { Vargas and Cabello } \\
\text { Helicoverpa armigera }\end{array}$ & Cotton & Spain, 1982 & Vargas and Cabello (1985) \\
Helicoverpa armigera & No data & Morocco, 1983 & Pintureau and Babault (1988) \\
Noctuidae & Tomato & Portugal, 1992 & Silva et al. (1999) \\
Sphingidae and Noctuidae & No data & Azores, 1989 & Pintureau et al. (1991) \\
Ectomyelois ceratoniae & No data & Algeria, 1979 & Pintureau and Babault (1988) \\
Palpita unionalis & Olive & Egypt, 2003 & This study, Hegazi et al. (2005) \\
T. bourarachae Pintureau and Babault & & & \\
Helicoverpa armigera & No data & Morocco, 1983 & \\
Noctuidae & Tomato & Portugal, 1992 & Pintureau and Babault (1988) \\
Vanessa cardui & Malva sylvestris & Morocco, 1992 & Silva et al. (1999) \\
Ectomyelois ceratoniae & Pomegranate & Rohi and Pintureau (2003b) \\
Host bait (Ephestia) & Olive & Tunisia, 2002 & This study \\
Host bait (Sitotroga), Palpita unionalis & Olive & Egypt, 2002, 2003, 2004 & This study \\
\hline
\end{tabular}


devices was observed, especially by ants in summer (Hegazi et al., 2005) and predators might have destroyed also parasitized eggs. Such positive samples were lost for further analysis. Nevertheless, the host exposure technique was shown to be a helpful tool to collect Trichogramma in the field. It can certainly be improved by using eggs of hosts known to occur in the sampling area and by a better protection from predators. The present work has clearly increased knowledge on the geographic distribution and species diversity of this important group of natural enemies and such surveys should be extended into other less studied areas of the world (Sithanantham et al., 2001).

\section{Acknowledgments}

This work was conducted with financial support from the European Commission within the specific program "Confirming the International Role of Community Research", contract ICA4-CT-2001-10004 (TRIPHELIO: Sustainable control of lepidopterous pests in olive groves-Integration of egg parasitoids and pheromones). We thank Mrs. Sybille Menke, Mrs. Hildegard Liscinsky, and Mrs. Doris Lotter for the skillful technical assistance and Dr. Martin Lange, DLR Rheinpfalz, Neustadt, Germany for support in molecular techniques. We gratefully acknowledge Dr. John Pinto, Univ. of California, Riverside, USA, for providing an English translation of the key of Sorokina (1993), Dr. Bernhard Pintureau, Inst. Nat. Sci. Appl. de Lyon, Villeurbanne, France, for identification of strains, Dr. Richard Stouthammer (Department of Entomology, University of California, Riverside, USA) for validation of ITS2-sequences and Dr. Isabel Silva, Wageningen University, The Netherlands, for the delivery of selected Trichogramma-strains for comparative studies. We dedicate this work to Mr. Ingo Possin who passed away too early.

\section{References}

Altschul, S.F., Madden, T.L., Schäffer, A.A., Zhang, J., Zhang, Z., Miller, W., Lipman, D.L., 1997. Gapped BLAST and PSI-BLAST: a new generation of protein database search programs. Nucleic Acids Res. 25, 3389-3402.

Arambourg, Y. (Ed.), 1986. Traite d'entomologie oleicole. International Olive Oil Council, Madrid, Spain.

Atanassov, A., Shearer, P.W., Hamilton, G.C., 2003. Peach pest management programs impact beneficial fauna abundance and Grapholita molesta (Lepidoptera: Tortricidae) egg parasitism and predation. Environ. Entomol. 32, 780-788.

Barnay, O., Hommay, G., Gertz, C., Kienlen, J.C., Schubert, G., Marro, J.P., Pizzol, J., Chavigny, P., 2001. Survey of natural populations of Trichogramma (Hym., Trichogrammatidae) in the vineyards of Alsace (France). J. Appl. Entomol. 125, 469-477.

Beaufoy, G., 2000. The environmental impact of olive oil production in the European Union: Practical options for improving the environmental impact. Report of the European Forum on Nature Conservation and Pastoralism. Comission of the European Communities, Brussels. Available at: http://europa.eu.int/comm/environment/agriculture/pdf/oliveoil.pdf.

Beaufoy, G., 2001. EU policies for olive farming. Unsustainable on all counts. Report by WWF Europe and BirdLife International. Printed by Artes Graficas Palermo, S.L. Available at: http://www.panda.org/ about_wwf/where_we_work/europe/what_we_do/policy_and_events/ epo/initiatives/agriculture/olive_sector_reform.cfm.

Browning, H.W., Melton, C.W., 1987. Indigenous and exotic Trichogrammatids (Hymenoptera: Trichogrammatidae) evaluated for biological control of Eoreuma loftini and Diatraea saccharalis (Lepidoptera: Pyralidae) borers on sugarcane. Environ. Entomol. 16, 360-364.

Cirio, U., 1997. Agrochemicals and environmental impact in olive farming. Olivae 65, 32-39.

EPPO, 2002. PM 6/3(2). Safe use of biological control. List of biological control agents widely used in the EPPO region. Bulletin OEPP/EPPO Bulletin 32, pp. 447-461.

Gerding, M., Cisternas, E., Céspedes, C., 1996. Use of Trichogramma in Rhyacionia buoliana control in Chile. In: Proceedings of the International Congress of Entomology, Florence, Italy, pp. 620.

Glenn, D.C., Hoffmann, A.A., 1997. Developing a commercially viable system for biological control of light brown apple moth (Lepidoptera: Tortricidae) in grapes using endemic Trichogramma (Hymenoptera: Trichogrammatidae). J. Econ. Entomol. 90, 370-382.

Gonçalves, C.I., Huigens, M.E., Verbaarschot, P., Duarte, S., Mexia, A., Tavares, J., 2006. Natural occurrence of Wolbachia-infected and uninfected Trichogramma species in tomato fields in Portugal. Biol. Control 37, 375-381.

Hassan, S.A., 1998. The suitability of Trichogramma cacoeciae as an indicator species for testing the side effects of pesticides on beneficial arthropods, compared to other hymenopterous parasitoids. IOBC/ WPRS Bull. 21, 89-92.

Hassan, S.A., Zhang, W.Q., 2001. Variability in quality of Trichogramma brassicae (Hymenoptera: Trichogrammatidae) from commercial suppliers in Germany. Biol. Control 22, 115-121.

Hegazi, E.M., Agamy, E., Hassan, S., Herz, A., Khafagi, W., Shweil, S., Abo-Abdala, L., Zaitoun, A., El-Said, S., El-Shazly, A., El-Menshawy, A., Karam, H., Khamis, N., El-Kemny, S., 2004. Application of inundantive releases of Trichogramma evanescens to control the olive moth, Prays oleae (Bern.). Egypt. J. Biol. Pest Control 14, 1-7.

Hegazi, E.M., Herz, A., Hassan, S., Agamy, E., Khafagi, W., Shweil, S., Zaitoun, A., Mostafa, S., Hafez, M., El-Shazly, A., El-Said, S., AboAbdala, L., Khamis, N., El-Kemny, S., 2005. Naturally occurring Trichogramma species in olive farms in Egypt. Insect Sci. 12, 185-192.

Herz, A., Hassan, S.A., Hegazi, E., Khafagi, W.E., Nasr, F.N., Youssef, A.A., Agamy, E., Jardak, T., Ksantini, M., Mazomenos, B.E., Konstantopoulou, M.A., Torres, L., Gonçalves, F., Bento, A., Pereira, J.A., 2005. Towards sustainable control of Lepidopterous pests in olive cultivation. Gesunde Pflanzen 58, 117-128.

Herz, A., Hassan, S.A., 2006. Are indigenous strains of Trichogramma sp. (Hym., Trichogrammatidae) better candidates for biological control of Lepidopterous pests of the olive tree? Biocontr. Sci. Technol. 16, 841-857.

Ibrahim, R., Holst, H., Basedow, T., 2004. Natural occurrence and distribution of Trichogramma spp. in vineyards of Rheingau (Hessia, Germany). Mitt. Dtsch. Ges. Allg. Ent. 14, 213-216.

Jardak, T., 1980. Etudes bioécologiques de Prays oleae BERN. (Lepidoptera, Hyponomeutidae) et de ses parasites oophages du genre Trichogramma (Hymenoptera, Trichogrammatidae) : essais d'utilisation en lutte biologique. Thèse de Doctorat de $3^{\text {éme }}$ cycle, Université de Droit, d'Economie et des Sciences d'Aix, Marseille, Faculté des Sciences et Techniques de Saint-Jérôme, 160 pp.

Li, L.Y., 1994. Worldwide use of Trichogramma for biological control on different crops: A survey. In: Wajnberg, E., Hassan, S.A. (Eds.), Biological Control with Egg Parasitoids. CAB International, Oxon, pp. 37-51.

Louda, S.M., Pemberton, R.W., Johnson, M.T., Follett, P.A., 2003. Nontarget effects - the Achilles heel of biological control? Retrospective analyses to reduce risk associated with biocontrol introductions. Annu. Rev. Entomol. 48, 365-396.

Pelekassis, C.E.D., 1962. A contribution to the study of nomenclature, taxonomy, biology, ecology and the natural parasitization of the olive 
kernel borer Prays oleae (Bernard). Ann. Inst. Phytopathol. Benaki, Nv. S. 4, 181-308.

Pinto, J.D., 1999. Systematics of the North American species of Trichogramma Westwood (Hymenoptera: Trichogrammatidae). Mem. Entomol. Soc. Wash. 22, 1-287.

Pinto, J.D., Stouthamer, R., 1994. Systematics of the Trichogrammatidae with emphasis on Trichogramma. In: Wajnberg, E., Hassan, S.A. (Eds.), Biological Control with Egg Parasitoids. CAB International, Oxon, pp. 1-36.

Pintureau, B., Babault, M., 1988. Systematique des espèces africaines des genres Trichogramma Westwood et Trichogrammatoidea Girault (Hym. Trichogrammatidae). Les Colloques de l'INRA 43, 97-120.

Pintureau, B., Oliveira, L., Anunciada, L., 1991. Contribution to the study of the egg parasitic Hymenoptera of the Azores islands. Les Colloques de l'INRA 56, 115-118.

Pintureau, B., Gerding, M., Cisternas, E., 1999. Description of three new species of Trichogrammatidae (Hymenoptera) from Chile. Can. Entomol. 131, 53-63.

Quayle, D., Regniere, J., Cappucino, N., Dupont, A., 2003. Forest composition, host-population density and parasitism of spruce budworm Choristoneura fumiferana eggs by Trichogramma minutum. Entomol. Exp. Appl. 107, 215-227.

Rey, P.J., 1995. Spatio-temporal variation in fruit and frugivorous bird abundance in olive orchards. Ecology 76, 1625-1635.

Rohi, L., Pintureau, B., 2003a. Reassessment of Trichogramma euproctidis (Girault, 1911) (Hymenoptera : Trichogrammatidae). Russ. Entomol. J. $12,373-379$.

Rohi, L., Pintureau, B., 2003b. Are Trichogramma bourarachae and the perkinsi species group really distinct from Trichogramma buesi and the pintoi group, respectively? J. Appl. Entomol. 127, 265-268.

Sakr, H., 2003. Use of egg parasitoids of the genus Trichogramma to control the codling moth Cydia pomonella (Lepidoptera: Tortricidae): selection of effective parasitoid species. Dissertation, University of Hohenheim. Verlag Ulrich E. Grauer, Beuren.

Sakr, H.E.A., Hassan, S.A., Zebitz, C.P.W., 2000. A new device to capture and monitor the activity of Trichogramma in the field. Mitt. Biol. Bundesanstalt 376, 578.

Schilthuizen, M., Stouthamer, R., 1997. Horizontal transmission of parthenogenesis-inducing microbes in Trichogramma wasps. Proc. R. Soc. Lond. B Biol. Sci. 264, 361-366.
Silva, I.M., Honda, J., van Kan, F., Hu, J., Neto, L., Pintureau, B., Stouthamer, R., 1999. Molecular differentiation of five Trichogramma species occurring in Portugal. Biol. Control 16, 177-184.

Sithanantham, S., Abera, T.H., Baumgärtner, J., Hassan, S.A., Lohr, B., Monje, J.C., Overholt, W.A., Paul, A.V.N., Wan, F., Zebitz, C.P.W., 2001. Egg parasitoids for augmentative biological control of lepidopteran vegetable pests in Africa. Insect Sci. Appl. 21, 189-205.

Sorokina, A.P., 1993. Key to species of the genus Trichogramma Westw. (Hymenoptera, Trichogrammatidae) of the World Fauna. Kolos Publishing House, Moscow . [In Russian].

Stouthamer, R., Hu, J., Van Kan, F.J.P.M., Platner, G.R., Pinto, J.D., 1999. The utility of internally transcribed spacer 2 DNA sequences of the nuclear ribosomal gene for distinguishing sibling species of Trichogramma. Biocontrol 43, 421-440.

Tezze, A.A., Botto, E.N., 2004. Effect of cold storage on the quality of Trichogramma nerudai (Hymenoptera, Trichogrammatidae). Biol. Control 30, 11-16.

Unruh, T.R., Messing, R.H., 1993. Intraspecific biodiversity in Hymenoptera: implications for conservation and biological control. In: LaSalle, J., Gauld, I.D. (Eds.), Hymenoptera and Biodiversity. CAB International, Wallingford, pp. 27-52.

Van Lenteren, J.C., Babendreier, D., Bigler, F., Burgio, G., Hokkanen, H.M.T., Kuske, S., Loomans, A.J.M., Menzler-Hokkanen, I., vanRijn, P.C.J., Thomas, M.B., Tommasini, M.G., 2003. Regulation of import and release of mass-produced natural enemies: a risk-assessment approach. In: vanLenteren, J.C. (Ed.), Quality Control and Production of Biological Control Agents. Theory and Testing Procedures. CABI Publishing, Wallingford, pp. 191-204.

Vargas, P., Cabello, T., 1985. A new species of Trichogramma (Trichogramma cordubensis $\mathrm{n}$. sp.) (Hym.: Trichogrammatidae) parasitoid of Heliothis eggs in cotton crops in the South West of Spain [Heliothis armigera]. Entomophaga 30, 225-230.

Walter, S., 1982. Zum Nachweis von Arten der Gattung Trichogramma Westwood in Forstbiozönosen der DDR. Entomol. Nachr. Ber. 26, $255-259$.

Youssef, A.A., Nasr, F.N., Stefanos, S.S., Abou Elkhair, S.S., Shehata, W.A., Agamy, E., Herz, A., Hassan, S.A., 2004. The side effects of plant protection products used in olive cultivation on the hymenopterous egg parasitoid Trichogramma cacoeciae Marchal. J. Appl. Entomol. 128, 593-599. 